\title{
THE IN VITRO RELEASE TESTING AND THE ANTIMICROBIAL ACTIVITY OF SEMI-SOLID DOSAGE FORMS WHICH CONTAIN SALICYLIC ACID
}

\author{
YELIZAVETA ZUIKINA ${ }^{1,2 *}$, NATALIA POLOVKO ${ }^{2}$, OKSANA STRILETS $^{3}$, LEONID $^{2}$ \\ STRELNIKOV $^{3}$
}

${ }^{1}$ Department of Drug Technology and Social Pharmacy, Lithuanian University of Health Sciences Sukilèliu pr. 13, Kaunas, Lithuania

${ }^{2}$ Department of Pharmaceutical Technology of Drugs, National University of Pharmacy, Valentinovska Street, Kharkiv, Ukraine

${ }^{3}$ Department of Biotechnology, National University of Pharmacy, Valentinovska Street, Kharkiv, Ukraine

*corresponding author: zujkina.lizaveta@gmail.com

Manuscript received: January 2021

\begin{abstract}
The aim of the work was to study the effect of the base nature on the salicylic acid release from semi-solid dosage forms by an in vitro method followed by the quantitative determination using high-performance liquid chromatography (HPLC). It has been found that salicylic acid is released from the Vaseline base in the least amounts, in a higher manner from the oil/water $(\mathrm{o} / \mathrm{w})$ emulsion base, and its maximum release is from the water/oil (W/O) base. A direct relationship between the degree of release and the antimicrobial properties of the ointment, in relation to the reference strains of the American type culture collection (ATCC): Staphylococcus aureus ATCC 25293, Bacillus subtilis ATCC 6633, Escherichia coli ATCC 25922, Pseudomonas aeruginosa ATCC 27853 and Candida albicans ATCC 885-653, has been determined. It has been found that a more complete release of the salicylic acid from ointments on emulsion bases increases their antimicrobial properties compared to the Vaseline base. It has been shown that the active substance is highly soluble in oil, and the antimicrobial effect will be more pronounced when using an emulsion base of the second type (W/O).
\end{abstract}

\section{Rezumat}

Scopul lucrării a fost de a studia efectul bazei formelor farmaceutice semi-solide asupra cedării acidului salicilic prin metoda in vitro urmată de determinarea cantitativă prin cromatografie de lichide de înaltă performanță (HPLC). Acidul salicilic este eliberat din baza de vaselină în cea mai mică cantitate, în cantitate mai mare din baza de emulsie ulei/apă (U/A), şi este eliberat complet din baza apă/ulei (A/U). A fost determinată relația directă între gradul de cedare și proprietățile antimicrobiene ale unguentului, în raport cu tulpinile de referință Staphylococcus aureus ATCC 25293, Bacillus subtilis ATCC 6633, Escherichia coli ATCC 25922, Candida albicans ATCC 885-653. S-a constatat că cedarea completă a acidului salicilic din unguente, având ca bază o emulsie, crește proprietățile lor antimicrobiene în comparație cu unguentele ce au ca bază vaselina. S-a demonstrat că substanța activă este foarte solubilă în ulei, iar efectul antimicrobian va fi potențat în cazul utilizării unei baze de tip emulsie A/U.

Keywords: release, HPLC, semi-solid dosage forms, microbiological studies

\section{Introduction}

An urgent task of modernizing extemporaneous compounding is to improve the composition of medicines produced for the future, first of all, due to the replacement of outdated Vaseline bases in the composition of semi-solid preparations (SSP) with emulsion ones [3]. An important stage in the development and improvement of the drugs composition, including SSP, is to determine the factors that affect the bioavailability and, primarily, the speed and completeness of the drug release [4]. Moreover, the necessary release of the active substances from the dosage form is a pre-requisite for the therapeutic effectiveness of the treatment $[16,21,22]$.
There are several methods for determining the bioavailability, the most widely used is the method of dialysis through a semipermeable membrane into an acceptor (dialysis) liquid. For drugs with antimicrobial activity the degree of activity in relation to the bacterial and fungal cells, depending on the number of variables, is indicative [1]. Using these biopharmaceutical methods in the development of SSP makes it possible to choose the optimal composition and predict the pharmacological activity of the composition selected.

Conducting the test of in vitro release using modified Franz diffuse cells is an important analytical tool that is applied to study and determine the behaviour of a soft drug form (SDF) depending on the formulation selected and is an important part of the drug development 
stage $[2,10,11,20]$. A simple and reproducible method using a vertical diffusion cell (VDC test system) and a synthetic membrane can be selected for the SDF quality control $[8,19]$. Drug release indicators provide basic information about the drug form and its behaviour, the release mechanism and kinetics; it allows choosing a more rational approach from a scientific point of view when developing a drug $[5,7]$. Changes in the release characteristics of the active substance can affect the effectiveness of the drug [17]. These changes may be related to the properties of active ingredients or excipients in the formulation, the process of manufacturing drugs, storage conditions, aging effects and other factors that are critical for the quality characteristics of the finished product $[6,14,15]$.

The rate of the active substances release in vitro is influenced by various physical and chemical parameters, such as solubility, the number and size of particles of the active substance, the type and nature of the base, the rheological properties of the semi-solid dosage form and solubility in the acceptor medium into which the active substance is released [24]. Therefore, we studied the effect of the nature of the base on the salicylic acid release from semi-solids by the in vitro method followed by the quantitative determination, using a HPLC method and the relationship between the degree of release of the active pharmaceutical ingredient (API) and the antimicrobial properties of the ointment in relation to the reference strains of microorganisms $[9,13]$.

\section{Materials and Methods}

The following emulsifiers were used for the preparation of the emulsion bases: Span 80 (sorbitan oleate), Span 60 (sorbitan monostearate), cetyl stearyl alcohol, Olevem 1000 (cetearyl olivate/sorbitan olivate), Emulpharma 1000 (cetearyl alcohol, glyceryl stearate, sorbitan stearate, cetearyl glucoside). $20 \%$ salicylic acid was the concentration chosen, taking into account that pharmacies prepared 2, 5 and $20 \%$ salicylic ointments with this substance as an active one. The study of the API release was performed in comparison with the salicylic ointment on the Vaseline base. The composition of the samples is presented in Table I.

Table I

The composition of the test samples

\begin{tabular}{|l|c|c|c|c|}
\hline \multicolumn{1}{|c|}{ The name of components } & \multicolumn{3}{c|}{ Quantitative content, \% / No. of samples } \\
\cline { 2 - 4 } & $\mathbf{1}$ & $\mathbf{2}$ & $\mathbf{3}$ & $\mathbf{4}$ \\
\hline Salicylic acid & 20 & 20 & 20 & 20 \\
\hline Corn oil & 40 & 10 & 15 & \\
\hline Span 80 (sorbitan oleate) & 2 & & & \\
\hline Span 60 (sorbitan Monostearate) & 3 & & & \\
\hline Cetyl stearyl alcohol & 5.5 & & & \\
\hline Olevem 1000 (cetearyl olivate/sorbitan olivate) & & 4 & & \\
\hline $\begin{array}{l}\text { Emulpharma 1000 (cetearyl alcohol, glyceryl stearate, sorbitan stearate, } \\
\text { cetearyl glucoside) }\end{array}$ & & & 6 \\
\hline Vaseline & & & \\
\hline Purified water & & \multicolumn{2}{|c|}{ Up to 100 } & 80 \\
\hline
\end{tabular}

Emulsion bases samples were obtained using the following technology: the required amount of emulsifiers was weighed on an electronic balance and melted on a water bath to a temperature of about $80^{\circ} \mathrm{C}$. Salicylic acid was previously dissolved in corn oil and added to the molten mixture of emulsifiers. After fusing the oil phase, the calculated amount of purified water pre-heated at $80^{\circ} \mathrm{C}$ was gradually added to it and homogenized using a laboratory homogenizer for 30 min to a uniform consistency, and then it was cooled to room temperature. Sample 4 was obtained using the following technology: the required amount of salicylic acid was weighed on an electronic balance and crushed with the required amount of ethanol. The weighed Vaseline was placed on a water bath. Vaseline was mixed with salicylic acid in a mortar and cooled to room temperature.

The in vitro study of the salicylic acid release from ointments on emulsion and Vaseline bases was performed using modified diffuse cells of Franz type with vertical diffusion cells (VDC) and Cuprophan regenerated dialysis cellulose membranes (Medicell International Ltd., London, UK) by a test system - model HDT 1000 for VDC testing. Filling cells for samples of SDF tested was from $250 \mathrm{mg}$ to $425 \mathrm{mg}$. The experiments with in vitro release were performed $(n=2)$. The area of membrane diffusion was $1.13 \mathrm{~cm}^{2}$.

The acceptor medium was chosen experimentally, investigating the dissolution of salicylic acid in 10, 20 and $30 \%$ solution of tween 80 . It was found that in $10 \%$ solution of tween 80 and salicylic acid is not completely soluble. $30 \%$ solution of tween- 80 interfered the chromatographic studies. Therefore, $30 \mathrm{~mL}$ of $20 \%$ solution of tween- 80 was chosen as the acceptor medium.

This is due to the fact that salicylic acid was indefinitely dissolved in this acceptor medium. The temperature of the acceptor medium was $32 \pm 1^{\circ} \mathrm{C}$. The samples of the acceptor medium $(1 \mathrm{~mL})$ were taken at $15 \mathrm{~min}, 1$, 1.5, 2 and 3 hours, and the same amount of a fresh 
medium was added to maintain a stable volume [19]. This time of the experiment was chosen due to the fact that the studies were aimed to determine the effect of the base type on the drug release.

The samples were filtered through a membrane filter $(0.22 \mu \mathrm{m})$ and analysed using HPLC.

UPLC-ESI-MS conditions

The separation of salicylic acid in samples was carried out with the Acquity H-class UPLC system (Waters, USA) equipped with a triple quadrupole tandem mass spectrometer (Xevo, Waters, USA) with an electrospray ionization source (ESI) used to obtain MS/MS data. The BEH C18 $(50 \times 2.1 \mathrm{~mm}, 1.7 \mu \mathrm{m})$ column was used for analysis. The column temperature was maintained at $40^{\circ} \mathrm{C}$. The gradient elution was performed with the mobile phase consisting of $0.1 \%$ formic acid water solution (solvent $\mathrm{A}$ ) and acetonitrile (solvent B), with the flow rate set to $0.5 \mathrm{~mL} / \mathrm{min}$. The linear gradient profile was applied with the following proportions of solvent A: 0 to $0.5 \mathrm{~min}-95 \%, 3.5$ min. $-5 \%, 3.55$ min back to $95 \%$. The negative electrospray ionization was applied for the analysis with the following settings: capillary voltage $-2.5 \mathrm{kV}$, source temperature $-150^{\circ} \mathrm{C}$, desolvation temperature $500^{\circ} \mathrm{C}$, desolvation gas flow $-800 \mathrm{~L} / \mathrm{h}$, cone gas flow $20 \mathrm{~L} / \mathrm{h}$. The collision energy was set to $12 \mathrm{eV}$ and the cone voltage was maintained at $30 \mathrm{~V}$. Precursor and product ions were selected at $137 \mathrm{~m} / \mathrm{z}$ and at $93 \mathrm{~m} / \mathrm{z}$, respectively.

Mass spectrometry conditions were optimized by running the scan first to determine the highest intensity signal of parent ion $(\mathrm{m} / \mathrm{z} 137)$ at different parameters (cone voltage and capillary voltage). By running daughter ion scan, optimal collision energy was determined by looking at the highest intensity of daughter ions ( $\mathrm{m} / \mathrm{z}$ of 93$)$.

Preparation of standard solutions of salicylic acid. The solution of salicylic acid in methanol with the concentration of $4 \mathrm{mg} / \mathrm{mL}$ was prepared from a standard sample. By diluting this solution with methanol, a series of solutions of $0.04,0.40,4.0,40.0,400.0$ and $4000.0 \mu \mathrm{g} / \mathrm{mL}$ was prepared. These solutions were used to plot a calibration graph.

The antimicrobial activity of samples with the ointments was studied in vitro, using the generally accepted biological agar diffusion method in the modification of wells $[1,23,25]$. As test cultures, the reference strains of the American type culture collection (ATCC), such as Staphylococcus aureus Gram-positive microorganisms ATCC 25293, Bacillus subtilis spore culture ATCC 6633; Escherichia coli Gram-negative cultures ATCC 25922, Pseudomonas aeruginosa ATCC 27853 were used. The antifungal action was determined in relation to a yeast-like fungus of the Candida genus Candida albicans ATCC 885-653 [23, 28].

During the experiments one-day suspensions of bacterial microorganisms in saline solution, and a twoday culture of a yeast-like fungus were used. The microbial load was $10^{7}$ colony-forming units of microorganisms in $1 \mathrm{~mL}$ of the nutrient medium $(\mathrm{CFU} / \mathrm{mL})$. When working with bacterial cultures, meat-andpeptone agar (MPA) was used, and the Sabouraud agar was used while working with a yeast-like fungus. Before conducting the research, the experiments were performed on the compliance of growth properties of nutrient media. It was experimentally proven that the growth properties of nutrient media met the requirements and cultures of microorganisms met the taxonomic designation of the strain by morphological, tinctorial and cultural properties.

The molten agar medium was introduced (10 $\mathrm{mL}$ each) in to Petri dishes, placed on a horizontal surface to form the lower layer. After solidification of the lower layer of agar on its surface at an equal distance from each other and from the edge of the dish, the sterile steel thin-walled cylinders were placed (the inner diameter $-6.0 \pm 0.1 \mathrm{~mm}$, the height $-10.0 \pm 0.1 \mathrm{~mm}$ ). The top layer of the nutrient medium was filled around the cylinders; it consisted of $15 \mathrm{~mL}$ of agar melted and cooled to $45-48^{\circ} \mathrm{C}$ and inoculated with a seed dose of the test microorganism. After cooling the upper layer, the cylinders were removed with sterile tweezers, and the same number of the test samples was put into the wells formed (samples' weight was $0.270 \pm 0.002 \mathrm{~g}$ ). Petri dishes were kept for $60 \mathrm{~min}$ at room temperature and placed in a thermostat for incubation: bacterial cultures at $35^{\circ} \mathrm{C}$ for $18-24 \mathrm{~h}$, the yeast-like fungus culture at $25^{\circ} \mathrm{C}$ for $48 \mathrm{~h}$.

The results were calculated by measuring the growth inhibition zone of microorganisms, including the diameter of wells. Measurements were with an accuracy of $1 \mathrm{~mm}$, thus focusing on the complete absence of the visible growth of the culture.

The following antimicrobial characteristics were used to assess the level of the antimicrobial activity of the samples: the absence of the growth inhibition zones of microorganisms around the well, as well as the inhibition zone with a diameter of up to $10 \mathrm{~mm}$ - an insensitive strain; $11-15 \mathrm{~mm}$ in diameter - a low sensitivity of the culture; $16-25 \mathrm{~mm}$ - as an indicator of a moderate sensitivity of the microbial strain; the diameter $>25 \mathrm{~mm}-$ a high sensitivity of the strain to the test samples.

The results of the antimicrobial studies were processed according to the method given by the SPhU (State Pharmacopoeia of Ukraine) in the section "Statistical analysis of the results of biological tests and quantitative determinations" [28].

\section{Results and Discussion}

Within the limits of salicylic acid concentrations from 0.04 to $4000 \mu \mathrm{g} / \mathrm{mL}$, the calibration graph is described by the following dependence equation: $\mathrm{Y}=-0.0464864 \times \mathrm{x} 2+201.382 \times \mathrm{x}+226.298$ (the correlation coefficient $\left.R^{2}=0.970455\right)$; the indicator 
fluctuates within the statistical error of concentrations, and the quantitative determination of these substances can be carried out with acceptable accuracy.

The results of the study of the salicylic acid release from model samples of ointments are shown in Figure 1.

The data obtained showed that the lowest amount of salicylic acid was released from the ointment on the fat (Vaseline) base. Compared with the average value of release from the samples of emulsion ointments the following data were obtained: in $15 \mathrm{~min}$ the release of the active substance was 16 times less, in 1 hour -9 times, in 1.5 hours -6 times, in 2 hours -7 times, in 3 hours -8 times [18].

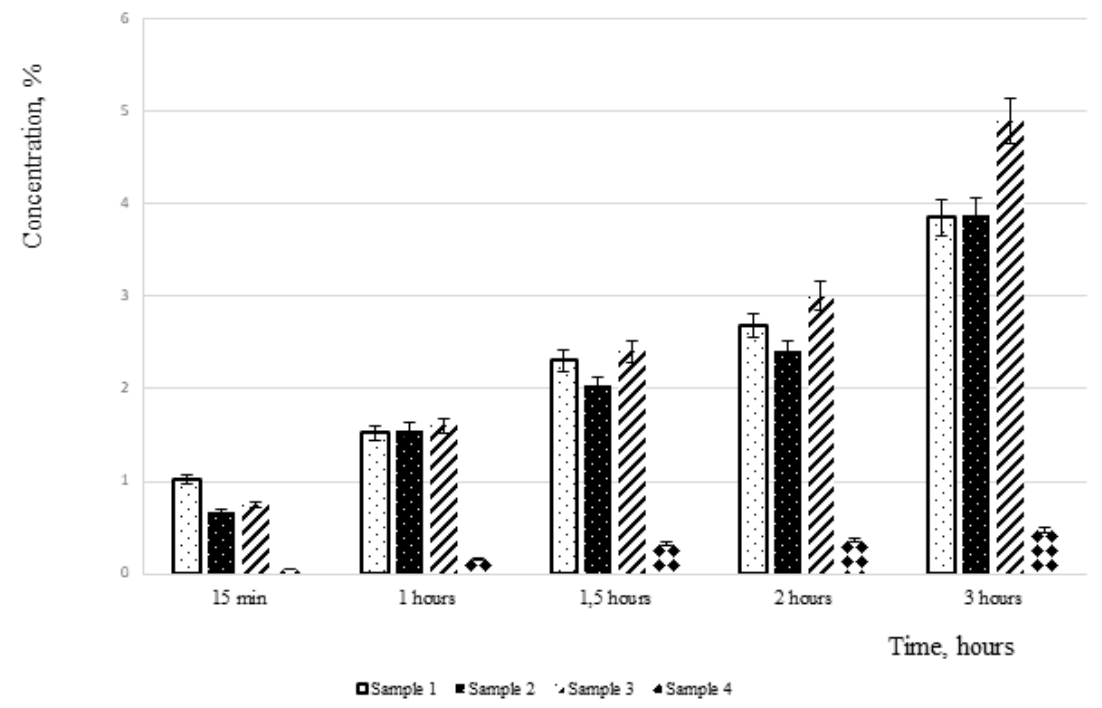

Figure 1.

Dynamics of the salicylic acid release from model samples of ointments

The results are consistent with studies showing that emulsion cream carriers are more effective than fatty ointments. The increase of bioavailability, rate of release and penetration of active ingredients, such as benzyl nicotinate and betamethasone valerate, is observed with a decrease in the fat content of the base [27].

Among emulsion bases the largest amount of salicylic acid was released by sample $\mathbf{1}$ - the emulsion base of the second type. Samples $\mathbf{2}$ and $\mathbf{3}$ showed almost no difference in the quantitative parameters of API release in the first hours. Moreover, it should be noted that sample 3, during the third hour of the experiment, released more of the drug substance than sample $\mathbf{2}$ with the same type of the emulsion base.

A marked decrease in the release of salicylic acid from $\mathrm{o} / \mathrm{w}$ emulsion bases is observed due to micellar solubilization of the drug in the aqueous phase of the $\mathrm{o} / \mathrm{w}$ emulsion. Among the kinetic and thermodynamic processes, the effect of thermodynamic activity predominates, which leads to a decrease in the rate of release of salicylic acid from the o/w emulsion compared to the w/o emulsion. Similar processes were detected during the release and penetration of ethyl p-aminobenzoate from the mineral oil in water $(\mathrm{o} / \mathrm{w})$ emulsion and the water in mineral oil (w/o) emulsion [12].Summarizing the obtained results, it should be noted that a higher release from the emulsion base of the second type may be associated with an easier passing of salicylic acid, which is soluble in the corn oil of the base dispersion medium, through the membrane, and the presence of surfactants increases the diffusion through the membrane [11].

In the studies conducted on the antimicrobial properties of semi-solid dosage forms with salicylic acid in relation to various cultures of microorganisms, the results shown Table II were obtained.

Table II

The results of the antimicrobial activity of the samples $(n=5)$

\begin{tabular}{|c|c|c|c|c|c|}
\hline \multirow{3}{*}{ Sample } & \multicolumn{5}{|c|}{ Cultures of microorganisms } \\
\cline { 2 - 6 } & $\begin{array}{c}\text { S. aureus } \\
\text { ATCC 25293 }\end{array}$ & $\begin{array}{c}\text { B. subtilis } \\
\text { ATCC 6633 }\end{array}$ & $\begin{array}{c}\text { E. coli } \\
\text { ATCC 25922 }\end{array}$ & $\begin{array}{c}\text { Ps. aeruginosa } \\
\text { ATCC 27853 }\end{array}$ & $\begin{array}{c}\text { C. albicans } \\
\text { ATCC 885-653 }\end{array}$ \\
\cline { 2 - 6 } & \multicolumn{5}{|c|}{ Diameters of growth inhibition zones of microorganisms, mm } \\
\hline 1 & $38.2 \pm 0.4$ & $32.2 \pm 0.4$ & $29.6 \pm 0.5$ & $28.2 \pm 0.4$ & $35.8 \pm 0.4$ \\
\hline 2 & $36.1 \pm 0.4$ & $29.1 \pm 0.6$ & $21.8 \pm 0.4$ & $23.0 \pm 0.3$ & $30.1 \pm 0.4$ \\
\hline 3 & $36.8 \pm 0.4$ & $30.2 \pm 0.4$ & $23.6 \pm 0.5$ & $25.6 \pm 0.5$ & $32.2 \pm 0.4$ \\
\hline 4 & $25.3 \pm 0.4$ & $16.3 \pm 0.4$ & $15.1 \pm 0.3$ & $13.4 \pm 0.3$ & $11.6 \pm 0.1$ \\
\hline
\end{tabular}


As evidenced by the results of the microbiological studies (Table II), all samples have a wide range of the antimicrobial activity, which level varied depending on the composition of the sample and the type of the test strain. It should be noted that the mechanism of action of salicylic acid is due to a change in the $\mathrm{pH}$ of the medium, which leads to denaturation of the protoplasm protein of a microbial cell.

A comparative analysis of the antimicrobial action of samples depending on the nature and composition of the bases showed that the highest antibacterial and antifungal activity was exhibited by the sample of the ointment with salicylic acid containing corn oil in the amount of $40 \%$, Span 80 and Span $60-2 \%$ and cetyl stearyl alcohol $-5.5 \%$ (sample 1). Thus, the growth inhibition zones of test strains were: in relation to $S$. aureus Gram-positive cultures ATCC 25293 - $38.2 \pm 0.4 \mathrm{~mm}$, B. subtilis ATCC $6633-$ $32.2 \pm 0.4 \mathrm{~mm}$; Gram-negative E. coli ATCC $25922-$ $29.6 \pm 0.5 \mathrm{~mm}, P$. aeruginosa ATCC $27853-28.2 \pm 0.4$ $\mathrm{mm}$. The antifungal activity in relation to $C$. albicans culture ATCC 885-653 was detected at the level of
$35.8 \pm 0.4 \mathrm{~mm}$. The experimental results obtained indicate that all the cultures of microorganisms used show a high sensitivity to this sample of ointment (the diameter of the growth inhibition is more than $25 \mathrm{~mm}$ ). The use of Vaseline as a base practically did not provide the salicylic acid release into the nutrient medium (sample 4); therefore, the antimicrobial activity was significantly lower compared to all samples.

The analysis of the ointments $\mathbf{2}$ and $\mathbf{3}$ with a different qualitative content of bases indicated that the test strains were also sensitive to the action of these samples. But sample $\mathbf{3}$ had a slightly higher antimicrobial activity compared to sample 2 . Thus, in relation to $S$. aureus ATCC 25293, the activity was $36.8 \pm 0.4$ and $36.1 \pm 0.4 \mathrm{~mm}$, respectively, to $B$. subtilis ATCC $6633-30.2 \pm 0.4$ and $29.1 \pm 0.6 \mathrm{~mm}$, to $E$. coli ATCC $25922-23.6 \pm 0.5$ and $21.8 \pm 0.4 \mathrm{~mm}$, to $P$. aeruginosa ATCC $27853-25.6 \pm 0.5$ and $23.0 \pm 0.3$ $\mathrm{mm}$, respectively. The antifungal activity in sample $\mathbf{3}$ was $32.2 \pm 0.4 \mathrm{~mm}$, while in sample $\mathbf{2}-30.1 \pm 0.4$ $\mathrm{mm}$ in relation to the culture of $C$. albicans ATCC 885-653 (Figure 2).

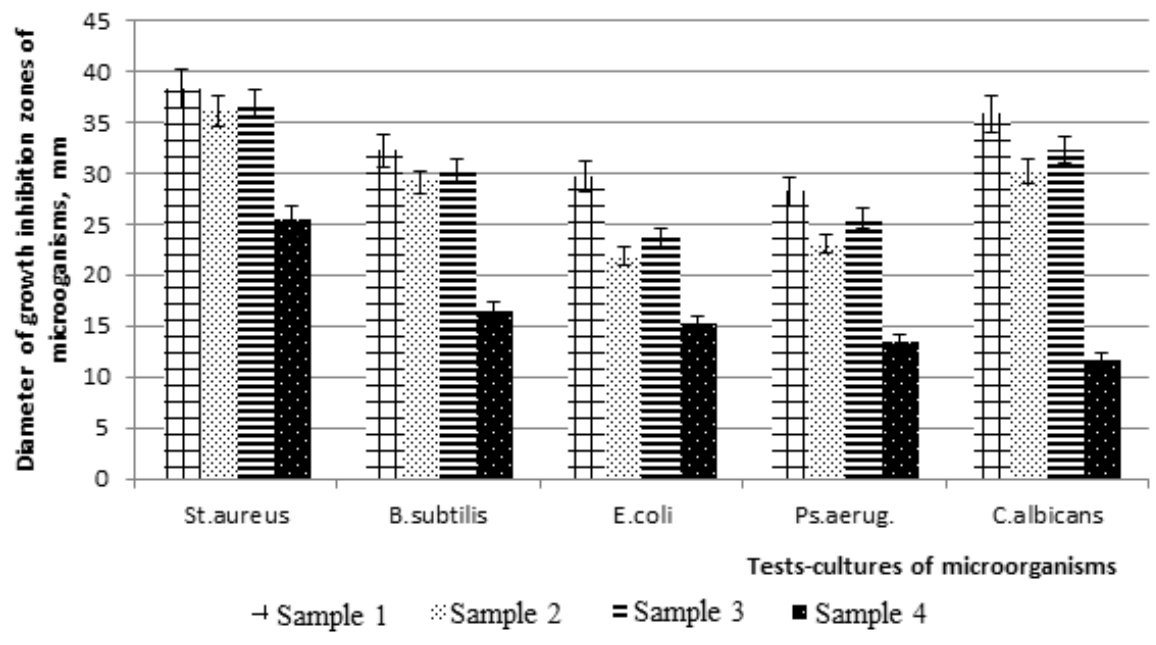

Figure 2.

Antimicrobial activity of ointment samples

It has been determined that the salicylic acid release from ointments on emulsion bases is more complete, which, in turn, increases the antimicrobial properties of the ointment compared to the fat (Vaseline) base. There is a direct relationship between the degree of release of the active substance and antimicrobial properties.

Therefore, the results of the microbiological studies have shown the impact of the base on the level of the antimicrobial action and are correlated with the results of the in vitro study of the API release. The prospects of using emulsion bases for semi-solid dosage forms with the antimicrobial activity in relation to cultures of both bacteria and fungi have been experimentally confirmed $[25,26]$.

\section{Conclusions}

The dependence of the degree of the salicylic acid release on the nature and composition of the ointment base has been studied. By using the method of modified Franz diffuse cells, with vertical diffusion cells, using HPLC for the identification of API in the acceptor liquid it has been determined that salicylic acid is more intensively and fully released from the water/oil emulsion base. When studying the antimicrobial activity of ointments, a wide range of activities and the dependence of the tested samples antimicrobial action on the nature and composition of the base have been found. It has been determined that the salicylic acid release from ointments on emulsion bases is more complete, and it increases, in turn, the antimicrobial properties of the ointment compared to the Vaseline 
base. There is a direct relationship between the degree of the active substance release and the antimicrobial properties. It has been shown that the active substance, which is highly soluble in oil, will have a more complete pharmacological effect when using emulsion bases of the second type.

\section{Acknowledgement}

The research was conducted under a collaboration agreement with the Lithuanian University of Health Sciences. The authors thank prof. Jurga Bernatoniene, the head of the Department of Drug Technology and Social Pharmacy, and prof. Valdas Jakstas, Department of Pharmacognosy of the Lithuanian University of Health Sciences, for providing premises and equipment for conducting our research.

\section{Conflict of interest}

The authors declare no conflict of interest.

\section{References}

1. Alsterholm M, Karami N, Faergemann J, Antimicrobial activity of topical skin pharmaceuticals - an in vitro study. Acta Derm Venereol., 2010; 90(3): 239-245.

2. Bhavsar JD, Brhambhatt VG, Patel MR, Patel KR, Patel NM, Novel approaches in semisolids. Int $J$ Pharm World Res., 2011; 2: 1-22.

3. Buhse L, Kolinski R, Westenberger B, Wokovich A, Spencer J, Chen CW, Turujman S, Gautam-Basak M, Kang GJ, Kibbe A, Heintzelman B, Wolfgang E, Topical drug classification. Int J Pharm., 2005; 295(12): 101-112.

4. Chang RK, Raw A, Lionberger R, Yu L, Generic Development of Topical Dermatologic Products: Formulation Development, Process Development, and Testing of Topical Dermatologic Products. AAPS J., 2013; 15(1): 41-52.

5. Chattaraj SC, Swarbrick J, Kanfer, I, A simple diffusion cell to monitor drug release from semi-solid dosage forms. Int J Pharm., 1995; 120(1); 119-124.

6. Corbo M, Shultz TW, Wong GK, Van Buskirk GA, Development and validation of in vitro release testing methods for semisolid formulations. Pharm Technol., 1993; 17: 112-128.

7. Desmedt B, Courselle P, De Beer JO, Rogiers V, Deconinck E, De Paepe K, In vitro Dermal Absorption: Sample Application and Seal Quality in a Franz Diffusion Cell System. Skin Pharmacol. Physiol., 2015; 28(5): 245-249.

8. FDA, Guidance for industry, SUPAC-SS: Nonsterile Semisolid Dosage Forms; Scale-Up and Post-Approval Changes: Chemistry, Manufacturing and Controls; In Vitro Release Testing and In Vivo Bioequivalence Documentation, Rockville, Center of Drug Evaluation and Research, 1997.

9. Hauck WW, Shah VP, Shaw SW, Ueda CT, Reliability and reproducibility of vertical diffusion cells for determining release rates from semisolid dosage forms. Pharm. Res., 2007; 24(11): 2018-2024.

10. Klein S, Influence of different test parameters on in vitro drug release from topical diclofenac formulations in a vertical diffusion cell setup. Pharmazie, 2013; 68(7): 565-571.

11. Klein RR, Bechtel JL, Burchett K, Thakker KD, Technical Note: Hydrocortisone as a Performance Verification Test Reference Standard for In Vitro Release Testing. Dissolution Technol., 2010; 37-38.

12. Lalor CB, Flynn GL, Weiner N, Formulation factors affecting release of drug from topical formulations. 1 . Effect of emulsion type upon in vitro delivery of ethyl p-aminobenzoate. J Pharm Sci., 1994; 83(11): 15251528.

13. Lusina Kregar M, Dürrigl M, Rožman A, Jelčić Ž, Cetina-Čižmek B, Filipović-Grčić J, Development and validation of an in vitro release method for topical particulate delivery systems. Int J Pharm., 2015; 485(1-2): 202-214.

14. Mitu MA, Cretu EA, Novac M, Karampelas O, Nicoara A, Nitulescu G, Lupuleasa D, The Flowing Characteristics of some composed powders containing inclusion complexes in beta-cyclodextrin. Proceedings Of The Romanian National Congress Of Pharmacy, $17^{\text {th }}$ Edition, 2018; 129-133.

15. Muntean AC, Negoi OI, Rus LL, Vonica A, Tomuţă I, Formulation of orodispersible tablets containing paracetamol and their in vitro characterization - A QbD approach. Farmacia, 2020; 68(3): 436-446.

16. Ng SF, Rouse J, Sanderson D, Eccleston G, A Comparative Study of Transmembrane Diffusion and Permeation of Ibuprofen across Synthetic Membranes Using Franz Diffusion Cells. Pharmaceutics, 2010; 2(2): 209-223.

17. $\mathrm{Ng}$ SF, Rouse JJ, Sanderson FD, Meidan V, Eccleston GM, Validation of a static Franz diffusion cell system for in vitro permeation studies. AAPS PharmSciTech., 2010; 11(3): 1432-1441.

18. Olejnik A, Goscianska J, Nowak I, Active compounds release from semisolid dosage forms. J Pharm Sci., 2012; 101(11): 4032-4045.

19. Parera Morell JL, Contreras Claramonte MD, Parera Vialard, Validation of a release diffusion cell for topical dosage forms. Int J Pharm., 1996; 137(1): 49-55.

20. Sesto Cabral ME, Ramos AN, Cabrera CA, Valdez JC, González SN, Equipment and method for in vitro release measurements on topical dosage forms. Pharm Dev Technol., 2015; 20(5): 619-625.

21. Shah VP, Williams RL, Importance of In Vitro Drug Release. In: Shah V, Maibach H, Jenner J (eds) Topical Drug Bioavailability, Bioequivalence, and Penetration. Springer, New York, NY., 2014; 61-67.

22. Shah VP, Elkins JS, Williams RL, Evaluation of the test system used for in vitro release of drugs for topical dermatological drug products. Pharm Dev Technol., 1999; 4(3): 377-385.

23. State Pharmacopoeia of Ukraine: in State Enterprise "Ukrainian Scientific Pharmacopoeial Center for Quality of Medicines", $2^{\text {nd }}$ ed., Kharkiv: State Enterprise "Ukrainian Scientific Pharmacopoeial Center for Quality of Medicines". 2015; 2(3): 1128, (available in Ukrainian).

24. Thakker KD, Chern WH, Development and validation of in vitro release tests for semisolid dosage forms case study. Dissolution Technol., 2003; 10(2): 10-15.

25. Thomson KS, Thomson GK, Biehle J, Deeb A, Crawford J, Herrera R, A Novel Topical Combination 
FARMACIA, 2021, Vol. 69, 6

Ointment with Antimicrobial Activity against MethicillinResistant Streptococcus aureus, Gram-Negative Superbugs, Yeasts, and Dermatophytic Fungi. Curr Ther Res Clin Exp., 2016; 83: 8-12.

26. Volyansky YuL, Gritsenko IS, Shirobokov VP, Study of the specific activity of antimicrobial drugs. Method Guidelines, 2004; 38, (available in Ukrainian).

27. Wirén K, Frithiof $H$, Sjöqvist C, Lodén M, Enhancement of bioavailability by lowering of fat content in topical formulations. $\mathrm{Br} J$ Dermatol., 2009; 160(3): 552-556.

28. Zuikina E, Polovko N, Silayva L, Kovaleva T, Biopharmaceutical choice justification of basis for dermatological ointment. Ukrainian Biopharmaceut J., 2018; 4(57): 10-14, (available in Ukrainian). 